\title{
Effect of Plant Density and Sowing Time on Growth and Yield of Mung Bean (VignaRadiata (L.) Wilczek) in Upland Rice-Mung Bean Intercropping on Land Sand Beach Samas Indonesia
}

\author{
Bhaskara Anggarda GS ${ }^{1}$, Prapto Yudono ${ }^{2}$, Sriyanto Waluyo \\ ${ }^{1}$ MSc student, Departement Agronomy, Gadjah Mada University, Indonesia \\ ${ }^{2}$ Lecture and researcher, Departement Agronomy, Gadjah Mada University, Indonesia
}

\begin{abstract}
The field experiment was conducted for four months, from December 2014 to April 2015, in the beach sand area of Samas Beach, Bantul, Yogyakarta. The research is conducted to observe the effect of planting density of mung bean and the planting time in intercropping with upland rice on the growth and yield of mung bean. The experiment consists of five treatments for the planting density of mung bean and two treatments for the planting time. Totally, there are 15 combinations of treatment with three replications prepared by using a split plot design (split plot). There has been a decline in mung bean production along with the decreasing of the density of mung bean in intercropping system with upland rice. P4 treatment shows the highest harvest in the intercropping treatments which is not significantly different from its monoculture, while the first planting shows the highest results of mung bean compared to the second planting time.
\end{abstract}

Keywords: Mung bean, density, planting time, growth, yield

\section{Introduction}

Mung bean is a prior commodity which is highly potential to be developed intensively. Since mung bean has high carbohydrates, protein, and phosphorus, the advantage of mung bean as people food is very important (Soverdaet al., 2008). In addition, the mung bean is a versatile plant which is mostly consumed in its form of seeds or sprouts (Sippai A.H et al, 2016). However, according to BPS data (2015c), throughout 2014, Indonesia has imported around 68 thousand tons of mung bean from several countries, and in 2015 during January-June, Indonesia still imported around 33 thousand tons of mung bean. The high level of the imports of mung bean illustrates the low production of mung bean in Indonesia. One of the factors inhibiting the production of mung bean is that the farmland is increasingly narrowed.

These days, the cultivation of mung bean is still done in a farm land and dry land which are getting limited. One of the alternatives that can be done is by utilizing marginal land in a beach sand area. Mung bean has the ability to grow in the lowlands to an altitude of $700 \mathrm{~m}$ above sea level. In order to grow and develop properly, mung bean requires optimal rainfall of 50-200 mm / month; with temperatures of $25-27^{\circ}$ $\mathrm{C}$ with a humidity of $50-80 \%$ and gets enough sunlight (Humaedah, 2014). This makes mung bean can tolerate dry condition and be able to grow in areas with erratic rainfall conditions (Meena, 2016). Mung bean is one of the plants which have nodules to survive in the sandy areas (Sri Handayani, 2005).

In addition to utilizing marginal lands, to increase the production of mung bean can also be done by making mung bean intercropped with other crops. One of the plants that can be intercropped with mung bean is upland rice. There are several reasons for choosing this combination, the first is that mung bean is a crop with low habitus while upland rice is a crop with high habitus, the second is that the root system of these plants are also different, mung bean is a deep rooted plant while upland rice is a fibrous rooted plant (Sobkowicz, 2006), as well as that mung bean is a very good alternate crop in intercropping with upland rice due to the fact that this plant is capable for fixation of free nitrogen from air performed by root nodule bacteria (Nina, 2003). Thus, substantially according to (Saeed et al., 1999) intercropping upland rice with mung bean can increase land productivity.

Morgano's research results et.al (2008) shows that the cropping patterns in intercropping system affect the outcome of mung bean and upland rice, and give effect to the decreasing of mung bean yield at the level of higher upland rice population. It shows the effect of upland rice competition tends to be greater than mung bean. As a result, it is necessary to regulate the cropping pattern carefully considering the population of upland rice in the planting area. The application of intercropping legume cover crops such as soybeans with upland rice has achieved the benefits, i.e the pattern of six-lines soybean followed by one-line of upland rice economically provides maximum benefit. This intercropping makes the growth and seed yield of black soybean as good as its monoculture (Wibowo, 2012).

For that reason, through this study we would like to know the influence of the proportion of the upland rice and mung bean in the intercropping system conducted in a beach sand area on the growth and yield of mung bean. 


\section{Material and Methods}

\subsection{Experimental site}

Table 1: The physical and chemical properties of the soil in Samas beach, Bantul, Indonesia

\begin{tabular}{|c|c|c|}
\hline Parameter & Value & Description \\
\hline \multicolumn{3}{|c|}{ Physical Properties } \\
\hline \multicolumn{3}{|l|}{-Texture } \\
\hline Sand & $98 \%$ & \multirow{3}{*}{ Sandy soil } \\
\hline Dust & $1 \%$ & \\
\hline Clay & $1 \%$ & \\
\hline$-\mathrm{BV}$ & $1,79 \mathrm{~g} / \mathrm{cc}$ & Fairly high \\
\hline$-\mathrm{BJ}$ & $2,75 \mathrm{~g} / \mathrm{cc}$ & Fairly high \\
\hline \multicolumn{3}{|c|}{ Chemical Properties } \\
\hline$-\mathrm{pH}\left(\mathrm{H}_{2} \mathrm{O}\right)$ & 5,19 & Acid \\
\hline -C-Organic & $0,09 \%$ & Very low \\
\hline -N-Total & $0,02 \%$ & Very low \\
\hline$-\mathrm{P} 2 \mathrm{O} 5$ & $128 \mathrm{ppm}$ & High \\
\hline -K-available & $2 \mathrm{ppm}$ & Very low \\
\hline -KTK & $1,37 \mathrm{cmol} / \mathrm{kg}$ & Very low \\
\hline
\end{tabular}

Research will be conducted in a beach sand area, in Samas, Bantul, Yogyakarta with a height of 10 meters above sea level. The soil of the experimental site was sandy with $\mathrm{pH}$ 5.9 and lowly organic carbon, nitrogen total, also available kalium but high pottasium (Table. 1).

\subsection{Treatments details}

The design applied in this research is split plot design. The influence of the proportion of the upland rice and mung bean (P) consists of 6 levels as the main plot, while the planting time of mung bean (W) consists of 2 levels as the sub plot. The main plot is arranged by using the basic design of RCBD (randomized complete block design). The experiment is repeated 3 times.

The factor employed in the main plot is the proportions of upland rice and mung bean, also mung bean monoculture (P):

1) Proportion of upland rice and mung bean $80: 20$ (P1),

2) Proportion of upland rice and mung bean $60: 40$ (P2),

3) Proportion of upland rice and mung bean 40:60 (P3),

4) Proportion of upland rice and mung bean 20:80 (P4),

5) Proportion of upland rice and mung bean 0: 100 (P5).

The factor employed in the subplot (sub plot) is the planting time of mung bean (W):

1) Intercropping mung bean during the vegetative phase of upland rice (0-60 DAS) (W1).

2) Intercropping mung bean during the generative phase of upland rice (65-115 DAS) (W2).

The experimental plot consists of 15 main plots, divided into 3 blocks as replicates. Each plot has $3 \times 4 \mathrm{~m}$ wide, the distance between blocks is $1 \mathrm{~m}$ length and the distance between plots within a block is $0,5 \mathrm{~m}$. The treatment sets the proportion of the of upland rice and mung bean in intercropping system with $25 \times 25 \mathrm{~cm}$ of planting distance for upland rice, and $25 \times 15 \mathrm{~cm}$ for the mung bean.

\subsection{Parameters Recorded}

Five plants are randomly selected from each plot and employed to measure the height of plant, plant dry weight, leaf size of plants, number of seeds per pod, seed weight per pod, weight of 100 seeds, and seed weight per plant.

\subsection{Statistical Analysis}

The data obtained will be tabulated and analyzed by $\mathrm{F}$ test to determine the effect of treatment attempted in the observed variables. If there is a significant difference between the treatments, there will be a further DMRT test at 5\% level.

\section{Results and Discussion}

\subsection{The Growth}

Based on the variance analysis (Table 2), on every parameter that is observed, treatment P5 has the highest value compared to other treatments (Table 1). It is assumed that in treatment P5, which is the mung bean monoculture, there is no competition with upland rice in the absorption of light and plant nutrients, so that the mung bean might grow more optimally without any interspecies competition.

On the other hand, in the planting time of mung bean treatment, the second planting time has a lower value than the first on all the parameters. In the second planting time there has been upland rice entering the generative phase, it is thought that the mung bean is not able to compete with upland rice crops in gaining the nutrients. This is presumably due to the fact that the condition of the upland rice root which is more stable makes mung bean not be able to compete for water and nutrients. Levitt (1980) states that the productivity of a plant will decrease in line with the declining of soil moisture and nutrients content caused by competition with other plants in the cropping system.

However, at the second planting time, mung bean crops do not experience the shade effects from upland rice plants so it does not cause etiolation. This is apparently due to their abundance of light intensity in the beach sand area and the fact that the structure and shape of the leaves, which are narrow and growing upward, do not shade the mung bean plants. This statement is in accordance to (Kim et al., 2005) that shading the mung bean plant under $25 \%$ does not affect the changes in the morphological characters of mung bean plant.

In addition, the mung bean is a $\mathrm{C} 3$ legume plant which has lower saturation level than that of $\mathrm{C} 4$ plants. Hence, this plant has good opportunity to develop in low light intensity conditions such as intercropping. Although in fact, the shade of mung bean results in reduced yield. According to Sunghening (2015), an increase in the intensity of the shade up to $25 \%$ results a decrease in mung bean yield by $34.5 \%$ 


\section{International Journal of Science and Research (IJSR) \\ ISSN (Online): 2319-7064 \\ Index Copernicus Value (2013): 6.14 | Impact Factor (2015): 6.391}

Tabel 2: The average result of observation on the parameters of plant height $(\mathrm{cm})$, number of leaves, leaf area $(\mathrm{cm} 2)$, dry weight (g), the number of branches, flowering dates (days), harvesting dates (days)

\begin{tabular}{|c|c|c|c|c|c|c|c|}
\hline Treatment & $\begin{array}{l}\text { Plant height } \\
(\mathrm{cm})\end{array}$ & $\begin{array}{l}\text { Number of } \\
\text { leaves }\end{array}$ & Leaf area $\left(\mathrm{cm}^{2}\right)$ & Dry weight (g) & $\begin{array}{l}\text { Number of } \\
\text { branches }\end{array}$ & $\begin{array}{l}\text { Flowering } \\
\text { dates (day) }\end{array}$ & $\begin{array}{l}\text { Harvesting } \\
\text { dates (day) }\end{array}$ \\
\hline \multicolumn{8}{|c|}{ Density } \\
\hline P1 & $24.48 \mathrm{c}$ & $10.83 \mathrm{a}$ & $1420.90 \mathrm{~d}$ & $21.66 \mathrm{c}$ & $7.00 \mathrm{~b}$ & $32.00 \mathrm{a}$ & $54.50 \mathrm{~b}$ \\
\hline $\mathrm{P} 2$ & $29.16 \mathrm{~b}$ & $11.50 \mathrm{a}$ & $1533.59 \mathrm{~b}$ & $25.18 \mathrm{~b}$ & $7.50 \mathrm{~b}$ & $32.00 \mathrm{a}$ & $55.33 \mathrm{~b}$ \\
\hline P3 & $29.85 \mathrm{~b}$ & $10.83 \mathrm{a}$ & $1443.02 \mathrm{~d}$ & $25.07 \mathrm{~b}$ & $7.83 \mathrm{~b}$ & $32.33 \mathrm{a}$ & $55.16 \mathrm{~b}$ \\
\hline $\mathrm{P} 4$ & $30.75 \mathrm{ab}$ & $11.50 \mathrm{a}$ & $1496.59 \mathrm{c}$ & $24.86 \mathrm{~b}$ & $8.67 \mathrm{a}$ & $32.50 \mathrm{a}$ & $55.33 \mathrm{~b}$ \\
\hline P5 & $35.13 \mathrm{a}$ & $12.00 \mathrm{a}$ & $1664.10 \mathrm{a}$ & $30.06 \mathrm{a}$ & $9.16 \mathrm{a}$ & $33.16 \mathrm{a}$ & $56.66 \mathrm{a}$ \\
\hline \multicolumn{8}{|c|}{ Sowing date } \\
\hline W1 & $34.15 \mathrm{~b}$ & $11.53 \mathrm{~b}$ & $1684.95 \mathrm{~b}$ & $30.92 \mathrm{~b}$ & $9.00 \mathrm{~b}$ & $33.53 \mathrm{~b}$ & $56.73 \mathrm{~b}$ \\
\hline W2 & $25.60 \mathrm{a}$ & $11.13 \mathrm{a}$ & $1338.33 \mathrm{a}$ & $19.81 \mathrm{a}$ & $7.06 \mathrm{a}$ & $31.26 \mathrm{a}$ & $54.06 \mathrm{a}$ \\
\hline CV (\%) & 7.99 & 3.62 & 1.04 & 4.62 & 5.56 & 1.26 & 0.86 \\
\hline
\end{tabular}

Description: The number followed by the same letter in the column and row are different according to DMRT $\alpha 0.05$

\subsection{Yield}

The same thing is also found in the result parameter, i.e. the number of seeds per pod, the seed weight per pod, the weight of 100 seeds, the seed weight per plant, the seed weight per plot and the seed weight per hectare (Table 2). Monoculture treatment for mung bean and the first planting time showed the highest result in the number of seeds parameter per pod, the seed weight per pod and the weight of 100 seeds. Similar to the weight parameters of seeds per plant, seed weight per plot and per hectare is also indicated by the monoculture treatment for mung bean with the first planting time, but the result tends to decrease along with the decreasing proportion of the mung bean in a cropping system. It is in line with the Singh et al., (2008) that the alternate crop will be lower than the main crop because of an interspecific competition between the two plants.

Tabel 3: The average result of observation on the parameter of number of seeds per pod, seed weight per pod, weight of 100 seeds, seed weight per plant, seed weightper plot and per hectare.

\begin{tabular}{|c|c|c|c|c|c|c|}
\hline Treatment & $\begin{array}{c}\text { Number of seed } \\
\text { per pod }\end{array}$ & $\begin{array}{c}\text { Seed weight per } \\
\text { pod (g) }\end{array}$ & $\begin{array}{c}\text { Weight of 100 } \\
\text { seeds }(\mathrm{g})\end{array}$ & $\begin{array}{c}\text { Seed weight per } \\
\text { plant }(\mathrm{g})\end{array}$ & $\begin{array}{c}\text { Seed weight } \\
\text { per plot (g) }\end{array}$ & $\begin{array}{c}\text { Seed weight per } \\
\text { hectare (ton) }\end{array}$ \\
\hline \multicolumn{7}{|c|}{ Density } \\
\hline P1 & $7.16 \mathrm{a}$ & $0.43 \mathrm{c}$ & $4.07 \mathrm{c}$ & $3.46 \mathrm{c}$ & $41.56 \mathrm{~d}$ & $0.14 \mathrm{e}$ \\
\hline P2 & $7.33 \mathrm{a}$ & $0.49 \mathrm{bc}$ & $4.03 \mathrm{c}$ & $3.91 \mathrm{c}$ & $62.56 \mathrm{~d}$ & $0.23 \mathrm{~d}$ \\
\hline P3 & $8.66 \mathrm{a}$ & $0.48 \mathrm{bc}$ & $4.93 \mathrm{~b}$ & $4.75 \mathrm{~b}$ & $114.12 \mathrm{c}$ & $0.43 \mathrm{c}$ \\
\hline P4 & $9.00 \mathrm{a}$ & $0.54 \mathrm{ab}$ & $5.38 \mathrm{a}$ & $4.97 \mathrm{ab}$ & $158.93 \mathrm{~b}$ & $0.55 \mathrm{~b}$ \\
\hline P5 & $9.16 \mathrm{a}$ & $0.56 \mathrm{a}$ & $5.41 \mathrm{a}$ & $5.62 \mathrm{a}$ & $246.91 \mathrm{a}$ & $0.86 \mathrm{a}$ \\
\hline \multicolumn{7}{|l|}{ Planting time } \\
\hline W1 & $8.60 \mathrm{a}$ & $0.52 \mathrm{a}$ & $4.88 \mathrm{a}$ & $5.11 \mathrm{a}$ & $136.99 \mathrm{a}$ & $0.48 \mathrm{a}$ \\
\hline W2 & $7.93 \mathrm{~b}$ & $0.47 \mathrm{~b}$ & $4.65 \mathrm{a}$ & $3.98 \mathrm{~b}$ & $112.64 \mathrm{~b}$ & $0.40 \mathrm{~b}$ \\
\hline CV (\%) & 7.96 & 6.69 & 3.88 & 8.15 & 9.52 & 9.46 \\
\hline
\end{tabular}

P4 treatment has a value that is not significantly different from P5 treatment which is the monoculture of mung bean on the parameters of seed weight per pod, weight of 100 seeds and seed weight per plant. These parameters are used to determine the size of the seed, where the seed size is an important characteristic in plant production. The size of the seeds depends on the amount of the carbohydrates supply from photosynthesis, because the establishment and development of seeds need a lot of carbohydrates.

Based on the analysis of variant (Table 3), all components of the results indicated the significant difference of planting time. At the first planting time, the mung bean plants are still able to compete with upland rice to fight over the available resources so that it produces the higher result compared with the second time planting of mung bean corp. The unsupportive environmental condition that does not support plant growth will directly affect the produced seeds (Banik et al., 2000). Besides, the presence of upland rice in the second planting time also results in the shade of the mung bean. It is assumed to affect the intensity of sunlight and the temperature received. As a result, the photosynthetic activity of mung bean is inhibited, and photosynthate and energy (ATP) are formed lesser. The photosynthate supplied to the plant also decreases during the generative phase, and this makes the pod's content reduce.

\section{Conclusion}

According to the findings above, it can be concluded that planting mung bean with intercropping system indicates a decreasing result due to the density of the mung bean and the planting time. Intercropping with $\mathrm{P} 4$ treatment is recommended because it has equally good results with monoculture treatment on the 100 seeds and seed weight per plant at the first planting time.

\section{Acknowledgements}

The authors express a deep gratitude to the Faculty of Agriculture, University of GadjahMada, Yogyakarta for the funding during this research.

\section{Volume 5 Issue 8, August 2016 www.ijsr.net}




\section{International Journal of Science and Research (IJSR) \\ ISSN (Online): 2319-7064}

Index Copernicus Value (2013): 6.14 | Impact Factor (2015): 6.391

\section{References}

[1] Soverda, N. Evitadan H. Arjuna, Pengaruhbeberapadosisabujanjangkelapasawitterhadapp ertumbuhandanhasilkacanghijau (Vignaradiata L.), JurnalAgronomi, 12(2), 2008, 3-5.

[2] Sipai, A.H., Jat, J.R. and Rathore, B.S., Effect of Phosphorus, Sulphur and Biofertilizer on Growth, Yield and Nodulation in Mungbean on Loamy Sand Soils of Kutch, Crop Research, 51(1),2016, 1-4

[3] BPSc, 2015. EkspordanImporBarang-Barang. Diaksesdarihttp://www.bps.go.id. Padatanggal 24 Maret 2016.

[4] Humaedah,

Ume, SyaratTumbuhdanBudidayaKacangHijau.

http://cybex.deptan.go.id/penyuluhan/syarat-tumbuhdan-budidaya-kacanghijau, 2014, (diakses 2 Juni 2016).

[5] Meena, S., Swaroop, N. and Dawson, J., Effect of integrated nutrient management on growth and yield of green gram (Vignaradiata L.).Agricultural Science Digest-A Research Journal, 36(1), 2016, 63-65.

[6] Sri Handayani, Kadar Fe, $\mathrm{Mg}, \mathrm{Ca}, \mathrm{Na}$, JaringandanPertumbuhanKacangHijau yang Diintroduksikan di LahanPasir di Daerah PatihanKawasanPantaiSamasBantul Yogyakarta denganPemberianMulsadanDosisPupukKandang, master thesis, Universitas Negeri Yogyakarta, Indonesia, M.Sc, 2005.

[7] Sobkowicz, P., 2006. Competition between triticale (Triticosecale Witt.) and field beans (Viciafaba var. minor L.) in additive intercrops. Plant Soil and Environment, 52(2), 2006, 47-58.

[8] Nina,

A,

Kajianwaktutanamdanjumlahbariskacanghijaudalamsist empertanamantumpangsaridenganpadigogo, master thesis, Universitas Gadjah Mada Yogyakarta, Indonesia, M.Sc, 2005.

[9] Saeed, M., A. Ullah, R. Ahmad and A. Jabbar, Bioeconomic assessment of direct-seeded ricebased intercropping systems under strip plantation. Pak. J. Bio. Sci. 2(3), 1999, 980-983.

[10] Morgado, LuizBalbino, and Robert William Willey, Optimum plant population for maize-bean intercropping system in the Brazilian semi-arid region, Scientia Agricola 65(5) (2008): 474-480.

[11] Wibowo, A,Pertumbuhandanhasilbenihkedelaihitam (Glycine max) malika yang ditanamsecaratumpangsaridenganjagungmanis. master thesis, Universitas Gadjah Mada Yogyakarta, Indonesia, M.Sc, 2012.

[12] Levitt, J., Responses of plants to environmental stresses. Volume II. Water, radiation, salt, and other stresses (No. Ed. 2).(Academic Press, 1980).

[13] Kim, D.K., Kim, J.B., Chon, S.U. and Lee, Y.S., antioxidant potentials and quantification of flavonoids in $\begin{array}{ll}\text { mung bean (Vignaradiata } & \text { L.) seeds. Plant }\end{array}$ Resources, 8(2), 2005, 122-129.

[14] Sunghening, W., \&Tohari, D. F. S. 2013. PengaruhMulsaOrganikTerhadapPertumbuhandanHasil TigaVarietasKacangHijau (Vignaradiata L. Wilczek) di LahanPasirPantaiBugel.

KulonProgo. Vegetalika, 1(2),2013, 54-66.
[15] Singh, U., Saad, A.A., Hasan, B., Singh, P. and Singh, S.R., Production potential and economics of intercropping of lentil (Lens culinaris) with brown sarson (Brassica compestris) and oat (Avena sativa). Indian Journal of Agronomy, 53(2), 2008, 135142

[16] Banik, P., Midya, A., Sarkar, B.K. and Ghose, S.S., Wheat and chickpea intercropping systems in an additive series experiment: Advantages and weed smothering. European Journal Agronomy, 24(4),2006, 325-332.

\section{Author Profile}

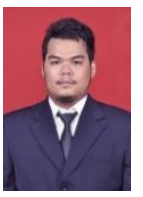

Bhaskara Anggarda is a graduate student at Agriculture Faculty, GadjahMada University, Indonesia. He held BSc degree in Agroecotechnology from Jenderal Soedirman University

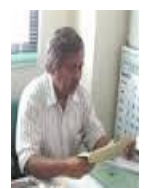

Prof. Dr. Ir. PraptoYudono, M.Sc. is senior lecture at Agriculture Faculty, University of GadjahMada, Indonesia. He held BSc degree in plant breeding at University of GadjahMada, than MSc and PhD from University of the Phillippines.

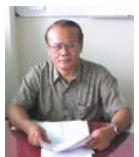

Dr. Ir. Sriyanto Waluyo, M.Sc. is senior lecture and at Agriculture Faculty, University of GadjahMada, Indonesia. $\mathrm{He}$ held $\mathrm{BSc}$ degree and $\mathrm{PhD}$ from university of Gajah Mada. 